\title{
Variation of morphological traits in natural populations of maritime pine (Pinus pinaster Ait.) in Morocco
}

\author{
Nadya WAHID ${ }^{\mathrm{a}, \mathrm{b}^{*}}$, Santiago C. GONZÁLEZ-MARTÍNEZ ${ }^{\mathrm{c}}$, Ismaïl El HADRAMI ${ }^{\mathrm{b}}$, Abdelali Boulli ${ }^{\mathrm{a}}$

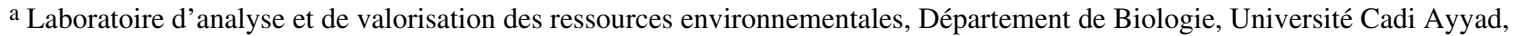 \\ Faculté des Sciences et Technique de Béni Mellal, BP 523, Béni Mellal, Morocco \\ ${ }^{\mathrm{b}}$ Laboratoire de physiologie végétale, Département de Biologie, Université Cadi Ayyad, Faculté des Sciences Semlalia, BP 2390, \\ 40000 Marrakech, Morocco \\ c Unidad de Genética Forestal, CIFOR-INIA, Carretera de La Coruña km 7.5, 28040 Madrid, Spain
}

(Received 2 June 2004; accepted 26 May 2005)

\begin{abstract}
Pinus pinaster Ait. is the main species used for reforestation in Morocco, both in mountain and low lands areas. However, little information is available about its intraspecific variation and adaptability in this range. This work studied the morphological variation of nine native populations, covering the distribution area of maritime pine in Morocco (Rif, Middle Atlas and High Atlas). Thirteen morphological and anatomical traits from cones (length and width), seeds (length, width, thickness and weight), seed wings (length and width) and needles (length, width, thickness and the number of stomata rows on the dorsal and convex faces of the needle) were measured in 232 trees. A Principal Component Analysis was used to explain the variation observed in four principal components related to cone (PCA3), seed (PCA1) and needle (PCA2 and PCA4) traits. Variability in morphological traits was high in Moroccan populations of maritime pine and significant differences among populations were found. Moreover, cone and needle traits showed clinal variation responding to latitude/altitude gradients. A hierarchical classification of all populations led to the formation of three major groups: (i) Mediterranean coastal populations, (ii) southeastern Rif, composed only by one population and (iii) the rest of populations, widely distributed through Moroccan maritime pine range.
\end{abstract}

maritime pine / geographic variation / morphological traits / natural populations / Mediterranean plants

Résumé - Variation des caractères morphologiques des populations naturelles du pin maritime (Pinus pinaster Ait.) au Maroc. Pinus pinaster Ait. est une espèce forestière habituellement choisie pour le reboisement au Maroc, aussi bien dans la montagne que dans la plaine. Cependant, peu de données sont disponibles sur sa variabilité et adaptabilité intra spécifiques dans ces milieux. Ce travail a permis d'étudier la variabilité morphologique de neuf populations indigènes, couvrant l'aire du pin maritime au Maroc (Rif, Moyen Atlas et Haut Atlas). Treize caractères morphologiques et traits anatomiques des cônes (longueur et largeur), des graines (longueur, largeur, épaisseur et poids), des ailes de graine (longueur et largeur) et des aiguilles (longueur, largeur, épaisseur et le nombre des lignes stomatiques sur les faces dorsales et convexes de l'aiguille) ont été mesurés sur 232 arbres. Une analyse en composantes principales a été employée pour expliquer la variance observée. Les quatre principaux axes correspondent à des caractères liés aux cônes (PCA3), aux graines (PCA1) et aux aiguilles (PCA2 et PCA4). La variabilité des caractères morphologiques est importante dans les populations marocaines de pin maritime et des différences inter populations significatives ont été mises en évidence. D'autre part, les caractéristiques des cônes et des aiguilles ont montré une variation clinale répondant aux gradients de latitude/altitude. La classification hiérarchique basée sur les caractères morphologiques de toutes les populations a conduit à l'individualisation de trois groupes principaux : (i) les populations de la côte méditerranéenne, (ii) une population du sud-est du Rif et (iii) le reste des populations, qui sont dispersées dans toute l'aire de répartition du pin maritime au Maroc.

pin maritime / variation géographique / traits morphologiques / populations naturelles / plantes méditerranéennes

\section{INTRODUCTION}

Patterns of variation within tree species depend on several factors, including geographic distribution, breeding system and historical events. The latter may include range fragmentation associated with climatic and landscape instability and changes in effective population size (e.g., bottlenecks or population expansions), which are both strong determinants of population genetic structure. Recent changes in forest policy in Morocco require managers to introduce alternative reforestation systems into plantations to provide greater structural diversity and enhance aesthetic values and environmental benefits. The development and implementation of the New Forest Management (NFM) plan implies the consideration of within-species genetic variability and adaptability. Main [32] listed the following five key scientific areas pertinent to an effective preservation of natural ecosystems: taxonomy and genetics, biogeography and evolution, regeneration and replacement ecology, resource recycling (i.e., how space and nutrients are made available for regeneration and growth) and risk assessment for land and water management.

* Corresponding author: wahid2na@yahoo.fr 
Table I. Location and geographic characteristics of nine native populations of Pinus pinaster Ait. in Morocco. Tmax and Tmin stand for mean maximum temperature and mean minimum temperature, NA: not available.

\begin{tabular}{|c|c|c|c|c|c|c|c|c|c|}
\hline Code & Population name & Region & Latitude & Longitude & Altitude (m asl) & Size (ha) & Rainfall (mm) & $\operatorname{Tmax}\left({ }^{\circ} \mathrm{C}\right)$ & $\operatorname{Tmin}\left({ }^{\circ} \mathrm{C}\right)$ \\
\hline $\mathrm{PC}$ & Punta cires & Rif & $35^{\circ} 55^{\prime} \mathrm{N}$ & $5^{\circ} 28^{\prime} \mathrm{W}$ & 40 & $25-175$ & 709 & 29.5 & 10.8 \\
\hline $\mathrm{KR}$ & Koudiat Erramla & Rif & $35^{\circ} 28^{\prime} \mathrm{N}$ & $5^{\circ} 23^{\prime} \mathrm{W}$ & 400 & 140 & 699 & 33.5 & 5.5 \\
\hline JB & Jbel Bouhacheme & Rif & $35^{\circ} 14^{\prime} \mathrm{N}$ & $5^{\circ} 25^{\prime} \mathrm{W}$ & 1094 & 95 & 2168 & 28 & 1.5 \\
\hline $\mathrm{ADL}$ & Adeldhal & Rif & $35^{\circ} 08^{\prime} \mathrm{N}$ & $5^{\circ} 09^{\prime} \mathrm{W}$ & 1450 & 168 & 1490 & 30 & 3.3 \\
\hline MAD & Madisouka & Rif & $35^{\circ} 11^{\prime} \mathrm{N}$ & $5^{\circ} 10^{\prime} \mathrm{W}$ & 1880 & 168 & 1483 & 31.9 & 2.3 \\
\hline TAD & Tadiwine & Rif & $34^{\circ} 56^{\prime} \mathrm{N}$ & $4^{\circ} 32^{\prime} \mathrm{W}$ & 1520 & 172 & 1501 & 21.6 & 0.5 \\
\hline TAMJ & Tamjout & Middle Atlas & $33^{\circ} 50^{\prime} \mathrm{N}$ & $3^{\circ} 59^{\prime} \mathrm{W}$ & 1550 & 130 & 422 & 37 & 4.2 \\
\hline TAL & Talaghine & Middle Atlas & $32^{\circ} 27^{\prime} \mathrm{N}$ & $5^{\circ} 14^{\prime} \mathrm{W}$ & 1840 & 20 & 362 & NA & NA \\
\hline SM & Sidi Meskour & High Atlas & $31^{\circ} 28^{\prime} \mathrm{N}$ & $6^{\circ} 50^{\prime} \mathrm{W}$ & 1910 & 96 & 556 & NA & $<0$ \\
\hline
\end{tabular}

Our work here provides insights related to the first and second topics of this broad classification of scientific areas.

Maritime pine (Pinus pinaster Ait.) is one of the most important forest species of the occidental Mediterranean basin and the Atlantic coastal region of southern Europe. Maritime pine is important both for ecosystem conservation (dunes protection) and economy (wood production and pulp and paper industry). Intraspecific variation in maritime pine has been investigated in several common garden experiments established in different countries: France [e.g. 26-28, 30, 41, 42], Greece [34], Spain [3, 4], Portugal [2], Turkey [51] and Australia [29]. These experiments showed that morphological and adaptive traits vary significantly over the range of maritime pine. On the other hand, wide-range studies using biochemical markers including terpenes [8], isozymes [40], denatured proteins [7] and chloroplast microsatellites [52] further confirmed high levels of geographic differentiation among populations in this species. Burban and Petit [13], based on mtDNA and RFLP analysis, have identified three maternal lineages in maritime pine, one of the lineages being specific of Morocco (i.e., the Moroccan lineage). The broad-scale differentiation indicated by these maternal lineages is also reflected in a wide range of molecular markers and quantitative traits [24].

In Morocco, maritime pine grows in natural stands on a variety of soil types and climatic conditions, both in mountain and low lands environments [16]. Genetic studies carried out on the Moroccan maritime pine provenances have primarily addressed biogeographic distribution [10] and provenance performance $[22,48]$. These results showed, in general, a higher phenotypical variability among populations growing in different regions rather than among populations from the same geographical area. The study by Harfouche et al. [27, 28], relevant to intraspecific hybrids of this species, revealed that the Moroccan population in the region of Tamjout was resistant to Matsucoccus feytaudi and that the hybrids of this provenance with other origins (e.g., Leiria in Portugal or Cazorla and Vivario in Spain) were also resistant to the pest. Tamjout is also considered as the most tolerant provenance to water and saline stresses in the maritime pine native range [25, 31, 37]. A recent study using allozyme markers showed that genetic variation of maritime pine in Morocco was highly structured $(\theta=10.44 \%)$. Three main groups of populations were distinguished based on genetic distances, namely (i) Occidental Rif, (ii) Oriental Rif and Middle Atlas and (iii) High Atlas [53].

In common practice, systematic inferences and taxonomic relationships are initially based on the analysis of morphological traits. Multivariate morphometric studies are considered to be effective to resole taxonomic uncertainty [14] and determine taxa within species complexes [39]. However, at the intraspecific level, patterns of morphological variation observed in nature might be misleading because morphological traits can be affected by environmental variation, so caution in the interpretation of patterns of differentiation is advisable. Nonetheless, these studies can be very useful in species or geographical ranges for which little information is available. Despite of the interest of Moroccan forest genetic resources, up-to-date only few studies dealt with variation in morphological traits, being based mainly on cones and needles [16, 17, 23].

The main objective of the present work is the analysis of the variation in morphological traits within and among Moroccan maritime pine populations. In addition, we are interested in the comparison between patterns of variation in morphological traits and those found in our previous studies [53] using neutral allozyme markers.

\section{MATERIALS AND METHODS}

\subsection{Sampling and measurements}

The distribution of maritime pine in Morocco is discontinuous, covering different biogeographic regions, which has resulted in local adaptation. We sampled nine natural populations corresponding to the Rif, the Middle Atlas and the High Atlas regions (Tab. I and Fig. 1). The samples were collected to serve an ambitious research program on maritime pine, including genetic diversity and ecophysiological studies, and are intended to fully represent variability among and within populations of Moroccan maritime pine. Methods of sampling individual trees and measurement of morphological characters were inspired in those of previous studies, such as Maley and Parker [33] and Boulli et al. [11]. A total of 232 trees (68 years old on average) collected according to population's size ( 16 to 35 trees per population) were sampled: 147 from the Rif region, 50 from the Middle Atlas, and 35 from the High Atlas. For each tree and for each character studied, we made 12 individual measurements. The main characteristics of the sampled stands are listed in Table I. Trees were chosen randomly, with 
Table II. Morphological and anatomical traits measured in Pinus pinaster Ait. populations from Morocco.

\begin{tabular}{lccc}
\hline Traits & Code & Unit of measurement & Method of measurement \\
\hline Cone traits & LC & $\mathrm{cm}$ & Caliper \\
Cone Length & WC & $\mathrm{cm}$ & Caliper \\
Cone Width & & $\mathrm{g}$ & Precision balance \\
Seed traits & WES & $\mathrm{cm}$ & Caliper \\
Seed Weight & LS & $\mathrm{cm}$ & Caliper \\
Seed Length & WS & $\mathrm{cm}$ & Caliper \\
Seed Width & DS & $\mathrm{cm}$ & Caliper \\
Seed Depth & LW & $\mathrm{cm}$ & Caliper \\
Wing Length & WW & & Caliper \\
Wing Width & & $\mathrm{cm}$ & Caliper \\
Needle traits & LN & $\mathrm{mm}$ & Caliper \\
Needle Length & WN & $\mathrm{mm}$ & $100 \times$ binocular microscope \\
Needle Width & DN & $\mathrm{counts}$ & $100 \times$ binocular microscope \\
Needle Depth & NSRD & counts & \\
Number of stomata rows on the & NSRC & & \\
dorsal face of the needle & Number of stomata rows on the & &
\end{tabular}

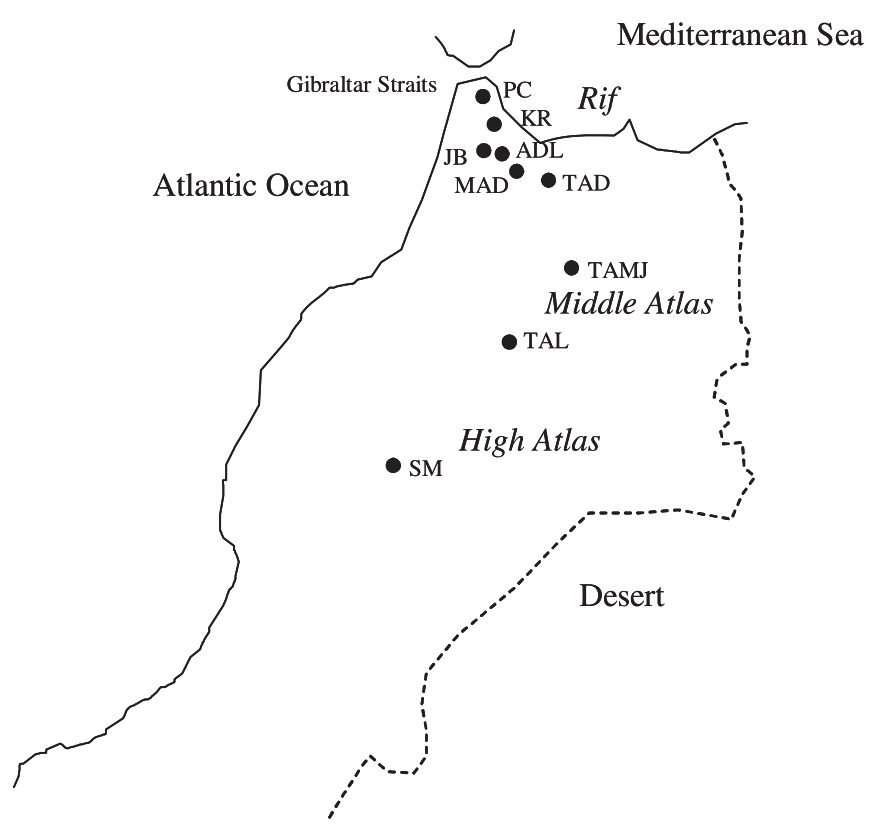

Figure 1. Location map of the nine native maritime pine populations sampled in this study.

no phenotypical selection, and were at least $50 \mathrm{~m}$ away from each other to avoid sampling from related individuals. On average, 20 ripe cones and 20 needles were collected from each tree during the summer of 2002.

Measured traits are cone length and width, seed length, width, depth and weight, wing length and width, needles length width and number of stomata rows on the convex and dorsal face of the needle. All meas- ures are carried out on dried and mature cones, healthy seeds and mature needles (see Tab. II for details). Some morphological traits were chosen based on previous work on discrimination between tree species (e.g., needle length [17, 23], seed wing length [9]). Measurements were taken on an average of 12 cones per tree using a caliper, 12 seeds per cone using a precision balance and 12 needles per tree using a $100 \times$ binocular microscope. Per tree averages were computed and used for further analysis.

\subsection{Data analysis}

We noticed a high correlation among some of the measured morphological variables (Tab. III). A Principal Component Analysis (PCA) was conducted on the individual-tree mean for each trait. The first four principal components (eigenvalue > 1), explaining $66.32 \%$ of the total variance in our dataset, were retained. The first principal component, PCA1, explained $28.00 \%$ of the total variance, while PCA2, PCA3 and PCA4 explained $18.52 \%, 10.93 \%$ and $8.87 \%$, respectively. A varimax rotation was applied and differences among populations for each trait and principal component have been analyzed using a one-way analysis of variance (ANOVA). Homogeneity of variance was tested by Levene's statistic and the observation of residual graphs. In addition, means were compared using Tukey tests for each series of ANOVA analysis.

Correlation between population means for each morphological trait and principal component, and environmental factors such as altitude, latitude, longitude and precipitation were studied using Spearman's non-parametric correlation coefficient. This correlation coefficient is adequate for samples of small size and non-normal distributions. Finally, a hierarchical cluster analysis was performed and a dissimilarity matrix was computed and subjected to an agglomeration method using the average linkage clustering between groups.

The statistical analysis of the data was carried out using the SPSS version 9.0 and the SAS version 8.0 statistical packages. 
Table III. Pearson coefficient of correlation between pairs of morphological traits determined for seeds, cones, wings and needles of Moroccan maritime pine populations (see Tab. II for abreviations).

\begin{tabular}{|c|c|c|c|c|c|c|c|c|c|c|c|c|c|}
\hline & WW & $\mathrm{WN}$ & WC & WS & LW & $\mathrm{LN}$ & $\mathrm{LC}$ & $\mathrm{LS}$ & NSRD & NSRC & WES & DN & DS \\
\hline WW & 1.000 & & & & & & & & & & & & \\
\hline WN & 0.022 & 1.000 & & & & & & & & & & & \\
\hline WC & 0.018 & -0.492 & 1.000 & & & & & & & & & & \\
\hline WS & 0.241 & $-0.879 * *$ & 0.434 & 1.000 & & & & & & & & & \\
\hline LW & 0.312 & -0.532 & 0.225 & $0.781^{*}$ & 1.000 & & & & & & & & \\
\hline $\mathrm{LN}$ & 0.159 & $0.916^{* *}$ & -0.505 & $-0.847 * *$ & -0.496 & 1.000 & & & & & & & \\
\hline LC & 0.252 & -0.508 & 0.485 & $0.778^{*}$ & 0.649 & -0.583 & 1.000 & & & & & & \\
\hline LS & 0.252 & -0.510 & 0.384 & $0.780^{*}$ & $0.906^{* *}$ & -0.575 & 0.634 & 1.000 & & & & & \\
\hline NSRD & 0.097 & $0.885^{* *}$ & -0.543 & $-0.813 * *$ & -0.441 & $0.814^{* *}$ & -0.661 & -0.380 & 1.000 & & & & \\
\hline NSRC & -0.057 & $0.820 * *$ & -0.264 & $-0.841^{* *}$ & -0.467 & $0.885^{* *}$ & $-0.702 *$ & -0.465 & $0.740 *$ & 1.000 & & & \\
\hline WES & 0.280 & $-0.857 * *$ & 0.570 & $0.962 * *$ & $0.712 *$ & $-0.873 * *$ & $0.780^{*}$ & -0.756 & $-0.807 * *$ & $-0.826 * *$ & 1.000 & & \\
\hline $\mathrm{DN}$ & 0.077 & $0.957 * *$ & -0.636 & $-0.823^{* *}$ & -0.465 & $0.839 * *$ & -0.501 & -0.476 & $0.903 * *$ & $0.692 *$ & $-0.796^{*}$ & 1.000 & \\
\hline DS & 0.209 & -0.600 & $0.731 *$ & 0.628 & 0.220 & -0.656 & 0.555 & 0.404 & $-0.696^{*}$ & -0.515 & $0.774 *$ & -0.635 & 1.000 \\
\hline
\end{tabular}

* Correlation is significant at the 0.05 level (2-tailed), ** Correlation is significant at the 0.01 level (2-tailed).

Table IV. One-way ANOVA of cone, seed, and needle traits in nine maritime pine populations in Morocco (see Tab. II for abbreviations). Significant values are represented by: $P<0.05$ : *; $P<0.01$ : $* * ; P<0.001$ : ***.

\begin{tabular}{lccc}
\hline Trait & \multicolumn{2}{c}{ Mean squares } & $F$ \\
\cline { 2 - 3 } & Among-populations & Within-populations \\
\hline Cone traits & & & \\
LC & 82.392 & 44.006 & 1.872 \\
WC & 1.529 & 0.119 & $12.859^{* * *}$ \\
Seed traits & & & \\
WES & 0.00093 & 0.00012 & $7.518^{* * *}$ \\
LS & 0.02820 & 0.00368 & $7.662^{* * *}$ \\
WS & 0.09700 & 0.01400 & $6.897 * * *$ \\
DS & 0.00328 & 0.00088 & $3.704 * * *$ \\
LW & 1.24700 & 0.07470 & $16.697 * * *$ \\
WW & 0.04270 & 0.00946 & $4.509^{* * *}$ \\
Needle traits & & & \\
LN & 60.289 & 2.706 & $22.283^{* * * *}$ \\
WN & 0.9650 & 0.0202 & $47.673^{* * *}$ \\
DN & 0.2740 & 0.0096 & $28.607^{* * *}$ \\
NSRD & 68.320 & 3.912 & $17.463^{* * * *}$ \\
NSRC & 58.255 & 2.173 & $26.812^{* * * *}$ \\
\hline
\end{tabular}

\section{RESULTS}

\subsection{Within-population variability}

High levels of morphological variation were found. The ANOVA indicated that most of the variation resided among populations, although a significant proportion of the total var- iance could be attributed to individual differences within populations (Tab. IV).

To estimate the proportion of intrapopulation variance, we computed the average within-population coefficient of variation (CV) based on population means and standard deviations (SD) for each trait (Tab. V). Our results showed that the seed weight had the highest intrapopulation variation of all (CV of $15.7 \%$ ). The number of stomata rows, both on the dorsal and convex faces of the needle, also presented a high variability within populations. The NSRD, for example, showed a CV of $16.5 \%$ while the WSRC's CV was $14.6 \%$. On the other hand, the seed width (WS) had the smallest intrapopulation CV (6.8\%). In general the needle traits showed the highest within population variability and the seed traits the lowest.

\subsection{Among-population variability}

Differences among populations for all measured traits were highly significant as shown by one-way ANOVA tests $\left(P<10^{-3}\right)$ with the exception of cone length that was only moderately significant $(P=0.057)$. Values of morphological and anatomical traits for needles, seeds and cones were highly correlated. The PCA1 had high factor loads of traits related to seed morphology (LS, DS, WS, WES, LW and WW) whereas PCA2 was correlated with most needles traits (DN, LN, NSRD and NSRC) and PCA3 represented cone size traits (LC and WC). Finally, PCA4 was highly correlated with needle width (0.92) and marginally correlated with cone length (-0.49). Among-population variability revealed remarkable features for different traits in maritime pine, as we describe below.

\subsubsection{Needle traits (LN, WN, DN, NSRD, NSRC)}

The Punta Cires population in the Occidental Rif showed the highest mean values for most needle characters with a needle length (LN) of $15.16 \pm 3.30 \mathrm{~cm}$, a needle width $(\mathrm{WN})$ of 


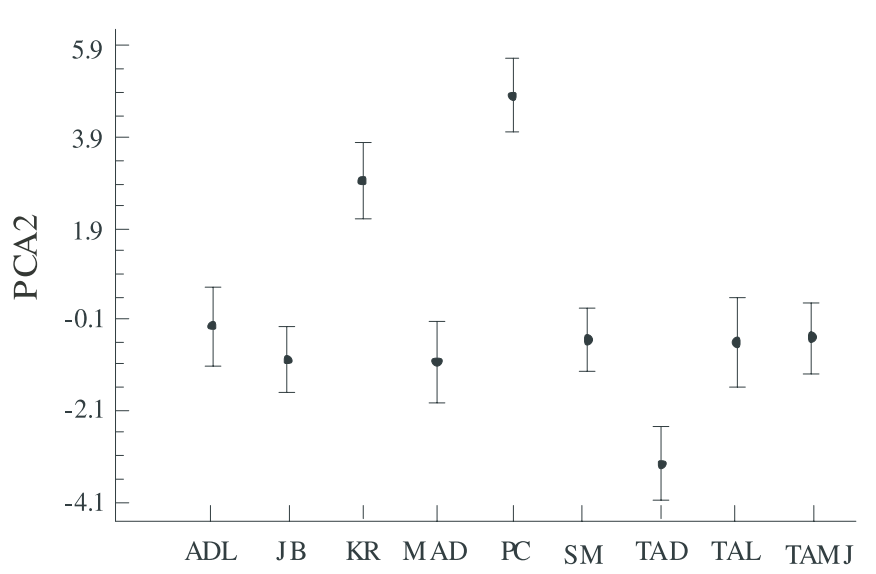

Figure 2. Population means and Tukey $95 \%$ confidence intervals for PCA2, which mainly represents needle traits.

$2.38 \pm 0.19 \mathrm{~mm}$ and a needle depth $(\mathrm{DN})$ of $1.16 \pm 0.10 \mathrm{~mm}$, while the lowest values (length $=11.06 \pm 1.60 \mathrm{~cm}$, width $=1.69 \pm$ $0.09 \mathrm{~mm}$ and depth $=0.71 \pm 0.08 \mathrm{~mm}$ ) were found in Tadiwine's (TAD) population also located in the Rif mountains but at a higher altitude (above $1500 \mathrm{~m}$ a.s.l). Similarly, the mean values of the number of stomata rows increased from $8.58 \pm 1.93$ (TAD) to $14.62 \pm 1.84(\mathrm{PC})$ for the dorsal face and from $9.13 \pm 1.13$ (TAD) to $13.45 \pm 1.75$ (PC) for the convex face of the needle, respectively. Differences between these characters in the PC and TAD locations were statistically significant, as shown by a Tukey test (Tab. V) for four out of the five morphological traits measured in this group. Additionally, for two of the traits (DN and NSRD), PC population appears to form a homogeneous group with Koudiat Erramla (KR), a nearby Rif population, suggesting that the populations of the two regions have strong similarities.

Differences among populations within the Rif region were obvious when population means for PCA2 (highly correlated with all needle traits except needle width) were computed (Fig. 2). In contrast, PCA4, mainly associated with needle width, did not show appreciable variation among populations (Tab. VI).

The results showed above indicate a subdivision in the Rif region according to morphological and anatomical traits for needles. The biggest needles were found at the Mediterranean coastal populations whereas the smaller ones were found at southeastern high altitude Rif locations.

\subsubsection{Seed traits (WES, LS, WS, DS, LW, WW)}

Differences among populations were less clear for seed traits than for needle traits. TAD population presented the highest mean values in seed weight $(0.065 \pm 0.011 \mathrm{~g})$, width $(0.48 \pm 0.03 \mathrm{~cm})$ and depth $(0.33 \pm 0.05 \mathrm{~cm})$. However, the test of separation of means using PCA1 (highly correlated with seed traits) did not clearly differentiate this population from the rest. The highest mean values for seed length $(0.87 \pm 0.09 \mathrm{~cm})$ were found at Talaghine (TAL), a Middle Atlas population. Punta Cires (PC) had low mean values of seed weight $(0.044 \pm 0.0072 \mathrm{~g})$, length $(0.73 \pm 0.04 \mathrm{~cm})$, width $(0.42 \pm 0.03 \mathrm{~cm})$ and depth $(0.29 \pm$
$0.02 \mathrm{~cm}$ ), but only the differences in seed weight from all the other populations were significant (Tab. V).

The wing length and wing width ranged from $2.49 \pm 0.22 \mathrm{~cm}$ (PC) to $3.34 \pm 0.38 \mathrm{~cm}$ (TAL) and $0.88 \pm 0.09 \mathrm{~cm}(\mathrm{TAMJ})$ to $1.00 \pm 0.08 \mathrm{~cm}(\mathrm{KR})$, respectively. Longer and larger wings were found in some populations from Occidental Rif and the Middle Atlas, but were not restricted to a geographic region. An inter-population comparison showed that wing width was more homogeneous, with an among-population coefficient of variation of $3.74 \%$ than wing length, having a coefficient of variation of $8.49 \%$.

\subsubsection{Cone traits}

The morphological traits characterizing cone size (length and width) showed again notable differences between Occidental Rif and southwestern Rif populations. The biggest cones were found at TAD population whereas PC and KR had some of the smallest. In fact, cone length and width varied from $10.52 \pm$ $1.39 \mathrm{~cm}(\mathrm{PC})$ to $12.87 \pm 1.31 \mathrm{~cm}(\mathrm{TAD})$ and $4.58 \pm 0.32 \mathrm{~cm}$ (PC) to $5.16 \pm 0.35 \mathrm{~cm}$ (TAD), respectively and the PC mean score $(-1.580 \pm 1.231)$ for PCA3 (associated to cone traits) was significantly different from the TAD score $(2.187 \pm 1.314)$.

\subsection{Geographical structure of morphological and anatomical traits}

The correlation between all morphological and anatomical traits and principal components from the PCA, with altitude, latitude, longitude and precipitation is shown in Table VII. Latitude is highly correlated with altitude $(-0.83)$, i.e. the southern populations are located at higher altitudes and these two effects cannot be differentiated. Cone traits are related to latitude/altitude. The biggest cones were found in high altitude populations in southern Morocco (correlation between WC and LC and altitude was 0.73 and 0.52 , respectively) but only the WC-altitude correlation was statistically significant at the $95 \%$ level. Most needle traits, on the contrary, were negatively correlated with altitude. The PCA3 (highly correlated with needle traits) showed significant correlation with altitude (0.72). Seed traits did not clearly correlate with any of the geographic parameters. Some of these traits were marginally correlated with rainfall (WES: 0.40 , DS: 0.55 and WW: 0.32 ) but the correlation were not statistically significant.

Finally, all morphological and anatomical traits were used in a hierarchical cluster analysis (Fig. 3). The resulting dendrogram allowed to distinguish three groups for this species in Morocco: (i) Mediterranean coastal populations, PC and KR, (ii) southeastern Rif, composed only by population TAD, and (iii) the rest of populations, covering most of the range of the species (JB, ADL, MAD, TAMJ, TAL and SM), with a slight differentiation of MAD population.

\section{DISCUSSION}

We found a high level of morphological variability among Moroccan populations of maritime pine. In particular, needle traits varied clinally with latitude/altitude and allowed the subdivision of Rif's populations in two groups: coastal and southeastern 


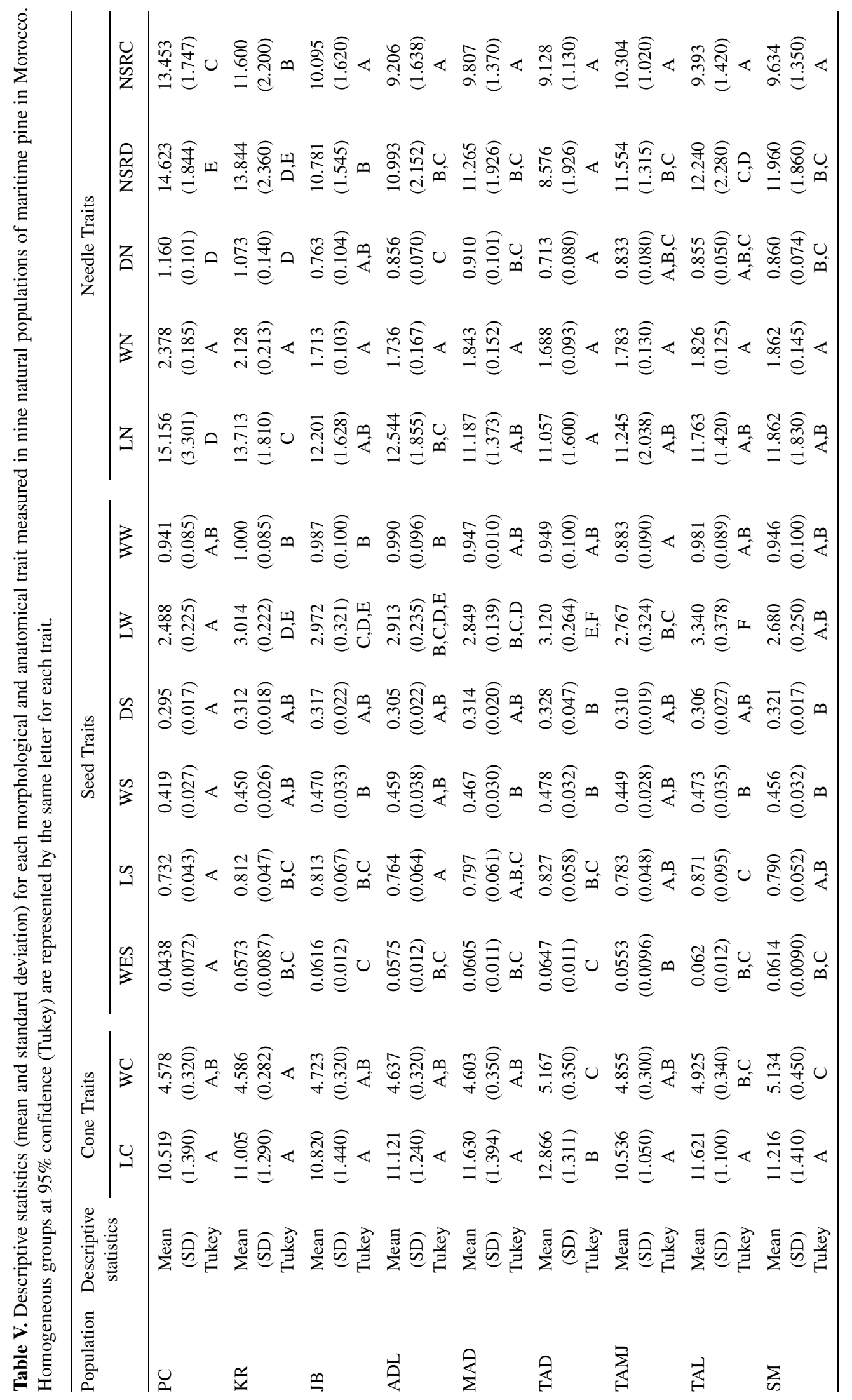


Table VI. Descriptive statistics (mean and standard deviation) for four principal components summarizing variation in morphological and anatomical traits of Moroccan maritime pine (see text for a description of factor loadings). Homogenous groups at $95 \%$ confidence (Tukey) are represented by the same letter for each trait.

\begin{tabular}{|c|c|c|c|c|c|}
\hline Population & $\begin{array}{l}\text { Descriptive } \\
\text { statistics }\end{array}$ & PCA1 & PCA2 & PCA3 & PCA4 \\
\hline PC & $\begin{array}{l}\text { Mean } \\
\text { (SD) } \\
\text { Tukey }\end{array}$ & $\begin{array}{c}-3.800 \\
(2.033) \\
\text { A }\end{array}$ & $\begin{array}{c}4.841 \\
(1.612) \\
\text { C }\end{array}$ & $\begin{array}{c}-1.580 \\
(1.231) \\
\mathrm{A}\end{array}$ & $\begin{array}{c}-0.300 \\
(0.453) \\
\text { A }\end{array}$ \\
\hline KR & $\begin{array}{l}\text { Mean } \\
\text { (SD) } \\
\text { Tukey }\end{array}$ & $\begin{array}{c}0.176 \\
(2.306) \\
\text { B,C }\end{array}$ & $\begin{array}{c}2.960 \\
(2.249) \\
\text { B }\end{array}$ & $\begin{array}{c}-0.860 \\
(1.207) \\
\mathrm{A}, \mathrm{B}\end{array}$ & $\begin{array}{c}-0.120 \\
(0.444) \\
\text { A }\end{array}$ \\
\hline JB & $\begin{array}{l}\text { Mean } \\
\text { (SD) } \\
\text { Tukey }\end{array}$ & $\begin{array}{c}1.113 \\
(3.377) \\
\mathrm{C}\end{array}$ & $\begin{array}{c}-1.000 \\
(2.000) \\
D\end{array}$ & $\begin{array}{c}-0.280 \\
(1.591) \\
\text { B,C }\end{array}$ & $\begin{array}{c}0.030 \\
(1.678) \\
\mathrm{A}\end{array}$ \\
\hline $\mathrm{ADL}$ & $\begin{array}{l}\text { Mean } \\
\text { (SD) } \\
\text { Tukey }\end{array}$ & $\begin{array}{c}-0.290 \\
(3.408) \\
\text { B,C }\end{array}$ & $\begin{array}{c}-0.260 \\
(2.220) \\
D\end{array}$ & $\begin{array}{c}-0.630 \\
(1.430) \\
\mathrm{A}, \mathrm{B}\end{array}$ & $\begin{array}{c}-0.260 \\
(0.478) \\
\mathrm{A}\end{array}$ \\
\hline MAD & $\begin{array}{l}\text { Mean } \\
\text { (SD) } \\
\text { Tukey }\end{array}$ & $\begin{array}{c}-0.050 \\
(2.338) \\
\text { B,C }\end{array}$ & $\begin{array}{c}-0.680 \\
(1.872) \\
D\end{array}$ & $\begin{array}{c}-0.010 \\
(1.348) \\
\text { B,C }\end{array}$ & $\begin{array}{c}0.100 \\
(0.648) \\
\text { A }\end{array}$ \\
\hline TAD & $\begin{array}{l}\text { Mean } \\
\text { (SD) } \\
\text { Tukey }\end{array}$ & $\begin{array}{c}2.213 \\
(3.175) \\
\text { C }\end{array}$ & $\begin{array}{c}-3.290 \\
(1.075) \\
\text { A }\end{array}$ & $\begin{array}{c}2.187 \\
(1.314) \\
D\end{array}$ & $\begin{array}{c}0.454 \\
(2.642) \\
\mathrm{A}\end{array}$ \\
\hline TAMJ & $\begin{array}{l}\text { Mean } \\
\text { (SD) } \\
\text { Tukey }\end{array}$ & $\begin{array}{c}-1.460 \\
(2.436) \\
\text { A,B }\end{array}$ & $\begin{array}{c}-0.500 \\
(1.331) \\
\text { D }\end{array}$ & $\begin{array}{c}-0.300 \\
(1.059) \\
\text { B,C }\end{array}$ & $\begin{array}{c}0.086 \\
(0.539) \\
\mathrm{A}\end{array}$ \\
\hline TAL & $\begin{array}{l}\text { Mean } \\
\text { (SD) } \\
\text { Tukey }\end{array}$ & $\begin{array}{c}2.229 \\
(2.419) \\
\text { C }\end{array}$ & $\begin{array}{c}-0.610 \\
(1.623) \\
D\end{array}$ & $\begin{array}{c}0.860 \\
(1.427) \\
\text { C,D }\end{array}$ & $\begin{array}{c}-0.010 \\
(0.563) \\
\mathrm{A}\end{array}$ \\
\hline SM & $\begin{array}{l}\text { Mean } \\
\text { (SD) } \\
\text { Tukey }\end{array}$ & $\begin{array}{c}-0.060 \\
(2.669) \\
\text { B,C }\end{array}$ & $\begin{array}{c}-0.550 \\
(1.685) \\
D\end{array}$ & $\begin{array}{c}0.603 \\
(1.522) \\
\mathrm{C}\end{array}$ & $\begin{array}{c}-0.110 \\
(0.464) \\
\text { A }\end{array}$ \\
\hline
\end{tabular}

Mediterranean populations. Cone traits also showed clinal variation with latitude and altitude, the biggest cones being collected in high altitude southern populations.

Our results are in line with those reported by Destremau [16] showing variation for seed length, wing color and cone weight in Moroccan maritime pine populations. Several other authors have shown remarkable differences among Mediterranean provenances of maritime pine (including Moroccan populations) in needle (length, depth, width and persistence) and cotyledon (length and number) traits [17, 23, 45]. Previous studies and our own results indicate high levels of morphological variability in Moroccan maritime pine. Although our samples may seem small, their independence and the random sampling technique used to select individuals make them statistically representative as each member of the population is equally likely to be chosen at any stage in the sampling process.

In a study of morphological variability of needles, cones, seeds and stems of one native Moroccan population from Middle Atlas (Tamrabta), Achouak [1] found high intra-population variation. In fact, the analysis of variance based on these morphological criteria showed highly significant differences among trees for most of the traits with the exception of the
Table VII. Spearman non-parametric coefficient of correlation between single morphological traits and principal components and geographic parameters (latitude, longitude, altitude and rainfall. Significant values are represented by: $P<0.05$ : *; $P<0.01$ : **; $P<0.001$ : ***.

\begin{tabular}{lcccc}
\hline Trait & Latitude & Longitude & Altitude & Rainfall \\
\hline Cone traits & & & & \\
LC & -0.433 & -0.133 & 0.517 & 0.083 \\
WC & $-0.867^{* *}$ & -0.083 & $0.733^{*}$ & -0.183 \\
Seed traits & & & & \\
WES & -0.350 & 0.050 & 0.333 & 0.400 \\
LS & -0.267 & -0.100 & 0.233 & 0.033 \\
WS & -0.600 & -0.100 & 0.533 & 0.100 \\
DS & -0.268 & -0.017 & 0.200 & 0.550 \\
LW & -0.133 & -0.333 & -0.017 & 0.100 \\
WW & 0.300 & 0.067 & -0.283 & 0.316 \\
Needle traits & & & & \\
LN & 0.633 & 0.650 & $-0.667^{*}$ & 0.067 \\
WN & $0.667 *$ & 0.100 & $-0.667^{*}$ & 0.400 \\
DN & 0.417 & 0.450 & -0.333 & -0.267 \\
NSRD & 0.183 & 0.483 & -0.267 & $-0.683^{*}$ \\
NSRC & 0.617 & 0.383 & -0.500 & -0.217 \\
Principal components & & & \\
PCA1 & -0.317 & 0.017 & 0.217 & 0.067 \\
PCA2 & 0.367 & 0.250 & -0.467 & -0.400 \\
PCA3 & $-0.717^{*}$ & -0.200 & $0.717^{*}$ & -0.017 \\
PCA4 & -0.400 & -0.600 & 0.467 & 0.117 \\
\hline
\end{tabular}

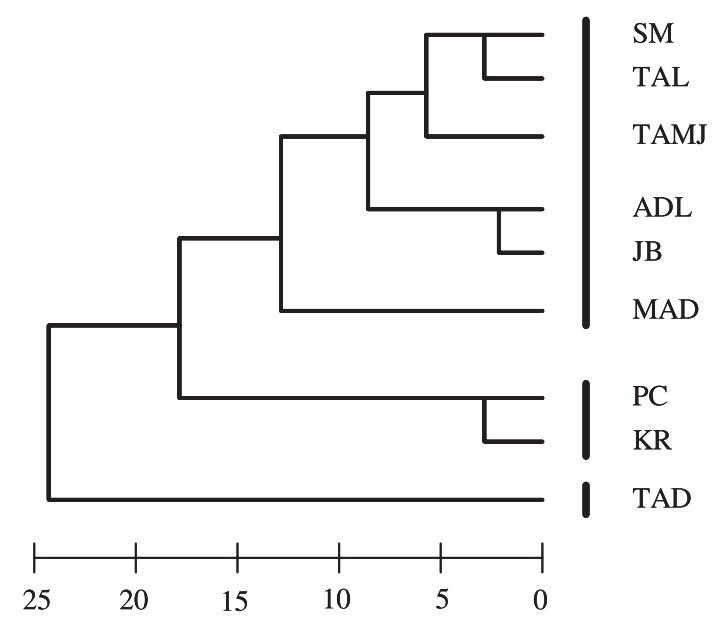

Figure 3. Dendrogram (hierarchical clustering) of nine natural population of Moroccan maritime pine based on morphological and anatomical traits.

number of whorls per tree, the number of branches per tree and stem straightness. High levels of morphological variation have also been found in other pine species from Morocco. Boulli et al. 
[11], studying 15 natural populations of Aleppo pine (Pinus halepensis Mill.) representing its natural distribution in Morocco, found a significant differentiation among localities. The higher variability was found in seed size, cone length and width and needle length, seed wing traits being more homogeneous throughout the entire Moroccan Aleppo pine range. Aleppo pine showed a clinal pattern of variation (latitudinal, altitudinal and longitudinal) in cone, needle and seed traits similar to that described here for maritime pine [11]. Other tree species have also shown high morphological variation in natural populations from Morocco (e.g., cork oak; [47]).

Our sampling covered a wide latitudinal (from $35^{\circ} 55^{\prime} \mathrm{N}$ to $36^{\circ} 28^{\prime} \mathrm{N}$ ) and longitudinal (from $5^{\circ} 28^{\prime} \mathrm{W}$ to $6^{\circ} 50^{\prime} \mathrm{W}$ ) range, including populations from costal regions at $40 \mathrm{~m}$ a.s.l. to $1910 \mathrm{~m}$ a.s.l. the High Atlas. The variation in climatic conditions might explain the differences in morphological traits between populations. The highest differences among populations were found in needle traits between Mediterranean coastal populations (PC and KR) and the southeastern Rif population TAD, which also had marked climatic differences (see Tab. I). Needles were largest in the lower lands of the Rif (PC) and smaller in the high-altitude population of TAD. In contrast, seeds and cones were largest in the high Rif and smaller in the low lands. Precipitation in the high-altitude Rif is two-fold the precipitation in the lowlands. In fact, populations PC and KR grow in major alluvial plains with Mediterranean influence (semi-arid to sub-humid climate) whereas the rest of the populations sampled belong to the humid climatic zone. Climate conditions appear to be important determinants of the morphological traits of pine trees. Needle morphology traits, such as stomatal density, appear to be linked to variations in water availability and temperature stress tolerance. It has been shown in some pine species that seedlings from drought-tolerant sources have shorter needles and fewer stomata per needle than seedlings from the drought-sensitive sources [15]. Our results suggest that the population of maritime pine in the higher Rif (TAD) might have adapted to drought conditions as it is characterized by shorter needles and smaller number of stomata compared to similar populations at lower altitude (PC) with moderate temperature and humidity regimes. In other study, using neutral allozyme markers [53] genetic differences were also found among Rif populations (PC/KR and TAD). Hence, a genetic component in the observed differences in morphology cannot be ruled out. In particular, Punta Cires population (PC) has previously been reported as belonging to a lineage different from the rest of Moroccan populations [13]. The evolutionary history of a region determines the distribution of the genetic variability within and among populations of a given species [6, 20, 49]. In Morocco, population differentiation of Rif's populations might have been favored by a complex geological history, including major glacial events, which led to a mosaic of soil types and climatic conditions $[19,43]$. Alternatively, the differentiation of these populations could have been promoted by old plantations using Iberian seed sources during the Spanish Protectorate in the region (1912-1956). Maritime pine was a frequent choice for reforestation in the 1940-1950's and the putative artificial origin of Punca Cires population has been suggested in early botanic studies of northern Morocco [46].

Variability of morphological and anatomical traits in needles and cones was correlated with latitude/altitude in Moroccan maritime pine. Early studies of variation in morphological traits in conifers have shown that phenotypic variation is frequently arrayed clinally in response to environmental gradients such as those for temperature or rainfall [50]. Monson and Grant [35] showed that the number of stomata rows on dorsal and convex faces in needles was, in part, related to an altitudinal gradient. Boulli et al. [11] and Parker et al. [38] showed clinal gradients (altitude, latitude and longitude) of morphological variation in cone, seed and needle traits and suggested an important role of natural selection and adaptation to a rapidly changing environment in the establishment of these patterns. Morphological and physiological acclimation responses are frequently reported in tree species [21, 33, 44]. For example, anatomical and morphological traits, such as those related to stomata or needle morphology, may be indirectly correlated with rainfall gradients because crown needles have different photosynthetic responses depending on their characteristics [5], a fact which has been linked to drought tolerance and preferences for a particular habitat [12], as well as to intraspecific population differentiation [18]. In maritime pine, significant differences among provenances were found concerning physiological adaptation to water stress in young seedlings [21, 29, 37].

In Morocco, a new framework for a fully integrated planning process in forest conservation and management is needed. Integrated goals need to be developed at various spatial scales to obtain an adequate arrangement of different serial stages and habitat types in Moroccan forests available for timber harvesting [36]. This would provide habitat diversity and facilitate post-logging regeneration. Knowledge on variability and identification of genetic and/or taxonomic units is critical in the domestication of any species. Morphometric and morphological trait analyses are useful to identify taxonomic units and to develop model bio-indicators to predict phenotypic responses to environmental variation. Key findings in this field could have important implications for habitat and biodiversity conservation and breeding. In our study, we found notable differences in morphological traits among maritime pine populations in Morocco. This information can be useful for the reforestation programs in Morocco as we identified some differences among populations that belong to the same geographic area. Indeed, the pattern of variation described for maritime pine in this paper reflected a larger variation in morphological traits than previously reported in the Moroccan range of this species. However, multisite common garden experiments would be needed in order to completely separate environmental and genetic factors explaining the observed level of natural variability.

Acknowledgements: This work was supported in part by grants D/ 1359 and D/2465 from the International Foundation for Science (IFS), Stockholm, Sweden. Santiago C. González-Martínez was funded by a Fulbright/MECD scholarship at University of California, Davis, USA. Thanks are extended to Patricia C. Grant who edited the English language. Special thanks to Dr. L. Bounoua who reviewed the document and provided valuable remarks.

\section{REFERENCES}

[1] Achouak K., Étude de la variabilité génétique du pin maritime (Pinus pinaster Ait.) de la forêt de Tamrabta, IAV Hassan II, Rabat, 1996. 
[2] Aguiar A., Roldão M.I., Esteves I., Baeta J., Ensaio de proveniências de Pinus pinaster Ait. Resultados de quatro anos de ensaio, Silva Lusitana 7 (1999) 39-47.

[3] Alía R., Gil L., Pardos J.A., Performance of 43 Pinus pinaster Ait. provenances on 5 locations in Central Spain, Silvae Genet. 44 (1995) 2-3.

[4] Alía R., Moro J., Denis J.B., Performance of Pinus pinaster Ait. provenances in Spain: Interpretation of the genotype-environment interaction, Can. J. For. Res. 27 (1997) 1548-1559.

[5] Aussenac G., Interactions between forest stands and microclimate: ecophysiological aspects and consequences for silviculture, Ann. For. Sci. 57 (2000) 287-301.

[6] Avise J.C., Phylogeography, the history and formation of species, Harvard University Press, Cambridge, Massachusetts, 2000.

[7] Bahrman N., Zivy M., Damerval C., Baradat P., Organization of variability of abundant proteins in seven geographical origins of maritime pine (Pinus pinaster Ait.), Theor. Appl. Genet. 88 (1994) 407-411.

[8] Baradat P., Marpeau A., Le pin maritime (Pinus pinaster Ait.) biologie et génétique des terpènes pour la connaissance et l'amélioration de l'espèce, Ph.D. dissertation, University of Bordeaux, Bordeaux, 1988.

[9] Beaulieu J., Simon J.P., Genetic structure and variability in Pinus strobus in Quebec, Can. J. For. Res. 24 (1995) 1726-1733.

[10] Benabid A., Étude phyto-écologique, biogéographique et dynamique des principales associations et séries sylvatiques du Rif occidental. Caractéristiques structurales des peuplements forestiers et problèmes posés pour leur aménagement (nord-ouest du Maroc), Ph.D. dissertation, St. Jérôme, Marseille, 1982.

[11] Boulli A., Baaziz M., M'hirit O., Polymorphism of natural populations of Pinus halepensis Mill. in Morocco as revealed by morphological characters, Euphytica 119 (2001) 309-316.

[12] Brix H., Effects of plant water stress on photosynthesis and survival of four conifers, Can. J. For. Res. 9 (1979) 160-165.

[13] Burban C., Petit R.J., Phylogeography of maritime pine inferred with organelle markers having contrasted inheritance, Mol. Ecol. 12 (2003) 1487-1495.

[14] Cook I.O., Ladiges P.Y., Morphological variation within Eucalyptus nitens s. 1. and recognition of a new species, E. denticulata, Aust. Syst. Bot. 4 (1991) 375-390.

[15] Cregg B.M., Carbon allocation, gas exchange, and needle morphology of Pinus ponderosa genotypes known to differ in growth and survival under imposed drought, Tree Physiol. 14 (1994) 883-898.

[16] Destremau D.X., Précisions sur les aires naturelles des principaux conifères marocains en vue de l'individualisation des provenances, Ann. Rech. For. Maroc 14 (1974) 3-90.

[17] Destremau D.X., Jolly H., Thari T., Contribution à la connaissance des provenances de Pinus pinaster, Ann. Rech. For. Maroc 16 (1976) 101-153.

[18] Dixon M.A., Johnson R.W., Interpretation of dynamics of plant water potential, in: Borghetti M.J., Grace J., Raschi A. (Eds.), Water transport in plants under climatic stress, Cambridge University Press, Cambridge, 1993, pp. 63-75.

[19] Emberger L., Travaux de Botanique et d'Écologie, Masson, Paris, 1971.

[20] Faith D.P., Conservation, evaluation and phylogenetic diversity, Biol. Conserv. 61 (1992) 1-10.

[21] Fernández M., Gil L., Pardos J.A., Effects of water supply on gas exchange in Pinus pinaster Ait. provenances during their first growing season, Ann. For. Sci. 57 (2000) 9-16.

[22] Ferrahi M., Contribution à l'étude de la variabilité intra-spécifique pour la vigueur et la qualité du bois chez Pinus pinaster dans l'ensemble expérimental de Bou Safi Larache, IAV Hassan II, Rabat, 1990.

[23] Ferre J., Les pins maritimes du Maroc, Laboratoire forestier de Toulouse, Toulouse, 1973.
[24] González-Martínez S.C., Mariette S., Ribeiro M.M., Burban C., Raffin A., Chambel M.R., Ribeiro C.A.M., Aguiar A., Plomion C., Alía R., Gil L., Vendramin G.G., Kremer A., Genetic resources in maritime pine (Pinus pinaster Ait.): molecular and quantitative measures of genetic variation and differentiation among maternal lineages, For. Ecol. Manage. 197 (2004) 103-115.

[25] Guehl J.M., Fort C., Ferh A., Differential responses of leaf conductance, carbon isotope discrimination and water-use efficiency to nitrogen deficiency in maritime pine and pedunculate oak plants, New Phytol. 191 (1995) 149-157.

[26] Guyon J.P., Kremer A., Stabilité phénotypique de la croissance en hauteur et cinétique journalière de la pression de la sève et de la transpiration chez le Pin maritime (Pinus pinaster Ait.), Can. J. For. Res. 12 (1982) 936-946.

[27] Harfouche A., Baradat P., Kremer A., Variabilité intraspécifique chez le pin maritime (Pinus pinaster Ait.) dans le sud-est de la France. I. Variabilité des populations autochtones de l'ensemble de l'aire de l'espèce, Ann. Sci. For. 52 (1995) 307-328.

[28] Harfouche A., Baradat P., Kremer A., Variabilité intraspécifique chez le Pin maritime (Pinus pinaster Ait.) dans le sud de la France. II. Hétérosis et combinaison des caractères chez des hybrides interraciaux, Ann. Sci. For. 52 (1995) 329-346.

[29] Hopkins E.R., Butcher T.B., Provenance comparisons of Pinus pinaster Ait. in Western Australia, CALM Science 1 (1993) 55- 105.

[30] Illy G., Recherches sur l'amélioration génétique du Pin maritime, Ann. Sci. For. 23 (1966) 757-948.

[31] Loustau D., Crepeau S., Santore M., Guye M., Saur E., Growth and water relations of three geographically separate origins of maritime pine (Pinus pinaster Ait.) under saline conditions, Tree Physiol. 15 (1995) 569-576.

[32] Main A.R., Keynote address: conservation, in: Hopper S.D., Chappill J., Harvey M., George A.S. (Eds.), Gondwanan heritage: past, present and future of the Western Australian biota, Surrey Beatty and Sons, Sydney, 1996, pp. 104-108.

[33] Maley M., Parker W., Phenology variation in cone and needle characters of Pinus banksiana, Can. J. Bot. 71 (1993) 43-51.

[34] Matziris D., Variation in growth and quality characters in Pinus pinaster provenance grown at seven sites in Greece, Silvae Genet. 31 (1982) 168-173.

[35] Monson R.K., Grant M.C., Experimental studies of ponderosa pine. III. Differences in photosynthesis, stomatal conductance and water efficiency between two genetic lines, Am. J. Bot. 76 (1989) 1041-1047.

[36] Nanson A., Certification des matériels forestiers de production: le nouveau système O.C.M.E., in: Actes du séminaire sur l'amélioration, la conservation et l'utilisation des ressources génétiques forestières Marocaines, ENFI Salé, Maroc, 1997, pp. 199-206.

[37] Nguyen A., Lamant A., Effect of water-stress on potassium distribution in young seedlings of maritime pine (Pinus pinaster Ait.), Ann. Sci. For. 46 (1989) 379-383.

[38] Parker A.J., Parker K.C., Faust T.D., Fuller M.M., The effects of climatic variability on radial growth of two varieties of sand pine (Pinus clausa) in Florida, USA, Ann. For. Sci. 58 (2001) 333-350.

[39] Passioura J.A., Ash J.E., Phenotypic, genetic and ecological variation in the Eucalyptus saligna-E. botryoides complex, Aust. J. Bot. 41 (1993) 393-412.

[40] Petit R., Bahrman N., Baradat P., Comparison of genetic differentiation in maritime pine (Pinus pinaster Ait.) estimated using isozymes, total protein and terpenic loci, Heredity 75 (1995) 382-389.

[41] Porté A., Bosc A., Champion I., Loustau D., Estimating the foliage area of maritime pine (Pinus pinaster Ait.) branches and crowns with application to modelling the foliage area distribution in the crown, Ann. For. Sci. 57 (2000) 73-86

[42] Pot D., Chantre G., Rozenberg P., Rodrigues J.C., Jones J.L., Pereira H., Hannrup B., Cahalan C., Plomion C., Genetic control of pulp and timber properties in maritime pine (Pinus pinaster Ait.), Ann. For. Sci. 59 (2002) 563-575. 
[43] Quezel P., Biogéographie et écologie des conifères sur le pourtour méditerranéen, in: Poisson A. (Ed.), Actualité d'écologie forestière, Gauthier-Villars, Paris, 1980.

[44] Reich P.B., Walters M.B., Tjoelker M.G., Vanderklin D., Buschea C., Photosynthesis and respiration rates depend on leaf and root morphology and nitrogen concentration in nine boreal tree species differing in relative growth rate, Funct. Ecol. 12 (1998) 395-403.

[45] Resch T., Essai de distinction morphologique des races majeures de Pinus pinaster Ait., Ann. Rech. For. Maroc 14 (1974) 91-102.

[46] Ruiz de la Torre J., El Matorral en Yebala, Instituto de Estudios Africanos, CSIC, Madrid, 1955.

[47] Sbay H., Ouassou A., Zitane L., Étude du polymorphisme morphologique du chêne liège, Séminaire sur la régénération du chêne liège dans le basin méditerranéen, Tabarka, 6-9 Nov., Tunisie, 1996.

[48] Sbay H., Arbez M., Pastuszka P., El-Alami S.L., Rachidai A., Ouassou A., Analyse de la variabilité adaptative du pin maritime au Maroc, Actes du séminaire sur l'amélioration, la conservation et l'utilisation des ressources génétiques forestières marocaines, ENFI Salé, Maroc, 1997, pp. 64-78.

[49] Schaal B.A., Haywood D.A., Olsen K.M., Rauscher J.T., Smith W.A., Phylogeographic studies in plants: problems and prospects, Mol. Ecol. 7 (1998) 465-474.

[50] Schoenike R.E., Natural variation in jack pine (Pinus banksiana Lamb.), Ph.D. Dissertation, University of Minnesota, Minneapolis, 1962.

[51] Simsek Y., Tulukcu M., Toplu F., Studies on the variations in growth and quality characteristics of Pinus pinaster Ait. provenance trials in Turkey, Ormancilik Arastirma Enstitusu Yayinlari, Ankara, 1985.

[52] Vendramin G.G., Anzidei M., Madaghiele A., Bucci G., Distribution of genetic diversity in Pinus pinaster Ait. as revealed by chloroplast microsatellites, Theor. Appl. Genet. 97 (1998) 456-463.

[53] Wahid N., González-Martínez S.C., El Hadrami I., Boulli A., Genetic structure and variability of natural populations of maritime pine (Pinus pinaster Ait.) in Morocco, Silvae Genet. 53 (2004) 93-99.

To access this journal online: www.edpsciences.org 